\title{
Tindak Kekerasan Terhadap Anak di Lingkungan Satuan Pendidikan dan Peranan Keluarga Sebagai Upaya Non-Penal Dalam Pencegahan
}

\author{
Oleh Jetty Martje Patty ${ }^{1}$, Cindy Agnesia Ratmala ${ }^{2}$ \\ jettymartjepatty69@gmail.com ${ }^{1}$; cindyratmala99@gmail.com ${ }^{2}$
}

Ilmu Hukum, Fakultas Hukum, Universitas Pattimura

\begin{abstract}
Schools are required to be anti violence zones, which provides a safe comfortable and enjoyable learning environment. Legal protection made by the government has not provided protection for children from violence that occurs in schools. So that there needs to be other efforts beyond legal measures that can prevent acts of violence against children in school. Non penal efforts through the role of the family.a as the first educational institution in society that plays a role in educating children to shape the character of children. Character education in the family will produce anti violence behavior in children themselves will distance themselves from behavior u violence, because children are equipped with loving behavior, tenderness, religious values, empathy in children.
\end{abstract}

Keyword : Non Penal. Efforts Violence.Educational Unit Environment

\section{PENDAHULUAN}

Tindak $\begin{array}{lr}\text { kekerasan } \\ \text { dingkungan satuan pendidikan }\end{array}$
dilakukang
didik terhadap peserta didik lainnya
akhir-akhir ini sering terjadi, dan
sudah mengarah kepada suatu tindak
kriminal yang menimbulkan terjadinya

korban baik fisik maupun phsikis..

Lingkungan pendidikan yang seharusnya menjadi lingkungan sekolah yang ramah anak, tiba-tiba saja berubah menjadi ring perkelahian atau penganiayaan yang menakutkan. Beberapa kasus tindak kekerasan yang dilakukan peserta didik terhadap sesama prserta didik lainnya di 
lingkungan satuan pendidikan pada beberapa wilayah di Indonesia antara lain kasus seorang siswa SMP Negeri 16 Malang (Jawa Timur) harus mengalami amputansi sebagian jari tengahnyanya akibat perundungan yang dilakukan oleh dua siswa kakak kelasnya. Korban diangkat dan dihempas ke lantai, menyebabken luka lebam di tangan, kaki dan punggung. Korban mengalami penderitaan fisik disamping guncangan psikologisnya kalau ditanya tentang peristiwa yang dialaminya, korban tertunduk dan menagis. Peristiwa tindak kekerasan juga dialami seorang siswa SMP di

\section{Daering Sumatra Barat yang} merenggang nyawa akibat perkelahian dalam kelas yang disebabkan saling ejek sesama kelas. Tindak kekerasan juga terjadi di salah satu sekolah SMP di Purworejo (Jawa Tengah), dimana salah satu siswi berkebutuhan khusus dipukul dan ditendang oleh tiga orang siswa di salah satu ruang kelas. Peristiwa itu disebabkan korban melapor kepada guru bahwa pelaku meminta uang dari korban. Oleh pelaku menyuruh temannya untuk mengambil fidio peristiwa penganiayaan tersebut . Dan ada banyak peristiwa tindak kekerasan lain yang masih saja terjadi di lingkungan sekolah yang tidak diangkat dalam media sosial.

Menurut Delfianto Quartita, kekeasan terhadap anak di lingkungan sekolah adalah setiap perbuatan yang berakibat timbulnya kesengsaraan atau penderitaan secara fisik, mental, seksual, psikologis termasuk perlakuan terhadap anak di lingkungan sekolah yang dikenal dengan istilah bullying. ${ }^{1}$

Sekolah wajib menjadi zona anti kekerasan sehingga peserta didik benar-benar merasakan suasana belajar yang aman, nyaman dan menyenangkan. Anak yang adalah peserta didik yang berada di lingkungan sekolah harus mendapat perlindungan dari tindak kekerasan, sebagaimana telah ditegaskan dalam Undang Undang nomor 23 tahun 2002 tentang perlindungan anak dan

\begin{tabular}{lll}
\hline \multicolumn{1}{c}{${ }^{1}$ Infopublik } & \multicolumn{2}{c}{ Solokkota } \\
go.id.Kekerasan Terhadap & Anak Di \\
Lingkungan Satuan Pendidikan & &
\end{tabular}


undang-undang nomor 35 tahun 2014 tentang perubahan atas undang-undang nomor 23 tahun 2002 tentang perlindungan anak yang dalam pasal 54 menyebutkan bahwa : anak di dalam dan di lingkungan sekolah wajib dilindungi dari tindak kekerasan yang dilakukan oleh guru, pengelola sekolah atau teman-temannya di dalam sekolah yang bersangkutan atau lembaga pendidikan lainnya. Adapun pelaksanaan terhadap pasal 54 ini telah dikeluarkan petunjuk pelaksanaanya melalui Peraturan Mentri Pendidikan Dan Kebudayaan Republik Indonesia nomor 82 tahun 2015 tentang pencegahan dan penanggulangan tindak kekerasan di lingkungan satuan pendidikan.

Perlindungan anak
merupakan segala kegiatan untuk
menjamin dan melindungi anak dan
hak-haknya agar dapat hidup tumbuh,
berkembang dan berpartisipasi secara
optimal sesuai harkat dan martabat
kemanusiaan , serta mendapat
perlindungan dari kekerasan da
diskriminasi. Perlindungan anak dari

tindak kekerasan di sekolah telah dilindungi oleh perangkat aturan hokum baik dalam undang-undang perlindungan anak mapun peraturan mentri.

\section{Perlindungan hukum yang} meliputi undang-undang dan peraturan mentri tersebut yang seharusnya dapat memberikan perlindungan bagi anak sebagai peserta didik di lingkungan pendidikan ternyata belum memberikan perlindungan yang baik bagi anak dari tindakan kekerasan yang terjadi di sekolah. Hal ini dapat terlihat dari masih adanya tindak kekerasan terhadap anak yang merupakan peserta didik di lingkungan sekolah, sehingga masih perlu adanya upaya lain selain upaya hukum (penal). Upaya lain dimaksud adalah upaya di luar hukum (non penal) yaitu melalui peranan keluarga sebagai lembaga pendidikan pertama dalam masyarakat yang berkewajiban mendidik dan membentuk karakter anak dalam mengantisipasi perilaku kekerasan pada anak. Salah satu pasal dalam undang-undang perlindungan anak 
juga telah memberikan suatu kewajiban dan tanggung jawab keluarga dan orang tua untuk mengasuh, memelihara, mendidik, dan melindungi anak. Untuk itulah maka permasalahan yang dimunculkan adalah bagaimana peranan keluarga sebagai upaya non penal dalam pencegahan tindak kekerasan terhadap anak di lingkungan satuan pendidikan.

\section{PEMBAHASAN}

Tindak kekerasan terhadap peserta didik adalah perilaku yang dilakukan secara fisik psikis, seksual dalam jaringan (daring) atau melalui buku ajar yang mencerminkan tindakan agresif dan penyerangan yang terjadi di lingkungan satuan pendidikan dan mengakibatkan ketakutan, trauma, kerusakan barang, luka/cedera, cacat dan kematian. Kasus-kasus kekerasan yang terjadi di lingkungan satuan pendidikan ternyata telah menimbulkan korban, dimana korban mengalami ketakutan, trauma, luka cedera, cacat dan kematian seperti yang dialami pesera didik dalam kasus kasus yang penulis angkat.
Berbagai bentuk tindak kekerasan yang dialami anak peserta didik yang terjadi di ligkungan sekolah antara lain berupa :

a. Pelecehan, merupakan tindakan kekerasan secara fisik, psikis atau daring.

b. Perundungan, merupakan tindakan mengganggu, menggusik terus menerus atau menyusahkan.

c. Penganiayaan, merupakan tindakan yang sewenangwenang seperti penyiksaan dan penderitaan.

d. Perkelahian, merupakan tindakan dengan disertai adu kata-kata atau adu tenaga.

e. Pemerasan, merupakan indakan, perihal cara, perbuatan memeras.

f. Pencabulan, merupakan tindakan proses, cara perbuatan keji dan kotor, tidak senonoh, melanggar 
kesopanan

dan

kesusilaan.

g. Pemerkosaan, merupakan tindakan,

perbuatan

proses, cara

meundukan dengan

kekerasan, memaksa

dengan

kekerasan,

dan/atau menggagahi.

h. Tindak kekerasan atas dasar diskriminasi terhadap suku,agama, ras, dan/atau antar golongan (SARA), merupakan segala bentuk

pembedaan,

pengecualian,

pembatasan

atau

pemilihan berdasarkan

pada SARA, yang

mengakibatkan

pencabutan

atau

penggurangan,

pengakuan perolehan atau

pelaksanaan atas hak

asasi manusia dan

kebebasan dasar dalam

suatu kesetaraan.
Pada dasarnya anak tidak dapat melindungi dirinya sendiri dari berbagai macam tindakan yang menimbulkan kerugiam mental, fisik dan social. Oleh sebab itu anak membutuhkan perlindungan dari orang lain. Perlindungan anak sebagaimana dirumuskan dalam undang-undang nomor 23 tahun 2002 tentang perlindungan anak bertujuan untuk menjamin terpenuhinya hak-hak anak agar dapat hidup, tumbuh, berkemmbang dan berpartisipasi secara optimal sesuai dengan harkat dan martabat kemanusiaan, serta mendapat perlindungan dari kekerasan dan diskriminasi, demi terwujudnya anak Indonesia yang berkualitas, berakhlak mulia dan sejahtera.

Persoalan perilaku kekerasan
yang dilakukan peserta didik di
sekolah merupakan persoalan perilaku
delinkuensi anak, Perilaku delinkuensi
anak yang merupakan terjemahan dari
istilah juvenile delinquency adalah
perilaku anak yang melanggar hukum
yang apabila dilakukan oleh orang
dewasa termasuk kategori kejahatan,


dalam hal ini termasuk perilaku pelanggaran anak terhadap ketentuan perundang-undangan yang khusus diperuntukan bagi mereka. ${ }^{2}$

Politik kriminal merupakan satu kebijakan atau usaha yang rasional untuk menanggulangi kejahatan. Menurut Sudarto politik kriminal adalah suatu usaha yang rasonal dari masyarakat dalam menanggulangi kejahatan.Kebijakan kriminal atau yang dikenal juga dengan kebijakan penanggulangan kejahatan pada hakekatnya merupakan bagian integral dari upaya perlindungan masyarakat (social defence) dan upaya mencapai kesejahteraan masyarakat (social welfare). Oleh karea itu dapat dikatakan bahwa tujuan akhir atau tujuan utama dari politik kriminal (kebijakan kriminal) ialah perlindungan masyarakat untuk mencapai keejahteraan masyarakat. ${ }^{3}$

Peraturan Mentri Pendidikan Dan Kebudayaan nomor 82 tahun 2015 pasal 2 menyebutkan bahwa untuk melindungi peserta didik dari tindak kekerasan maka pencegahan dan penanggulangannya perlu dilakukan hal ini dimaksudkan untuk :

a. Terciptanya kondisi proses pembelajaran yang aman, nyaman dan menyenangkan.

b. Terhindarnya semua warga sekolah dari unsur-unsur atau tindakan kekerasan.

c. Menumbuhkan kehidupan pergaulan yang harmonis dan kebersamaan antar peserta didik atau antar peserta didik dengan pendidik, tenaga kependidikan, dan orang tua serta masyarakat baik dalam satu satuan pendidikan maupun antar satuan pendidikan.

\footnotetext{
2 Paulus Hadisuprapto, Juvenile Delinquency Pemahaman dan Penanggulangannya , Citra Dditya Bakti, Bandung 1997. Hal 189
}

\footnotetext{
3 Barda Nawawi Arif, Bunga Rampai Kebijakan Hukum Pidana, Citra Aditya Bakti . Bandung 1996. 67
} 
Pencegahan dan penanggulangan tindak kekerasan di lingkungan satuan pendidikan bertujuan sebagaimana disebutkan dalam pasal 3 adalah untuk

a. Melindungi anak dari tindakan kekerasan yang terjadi di lingkungan satuan pendidikan maupun dalam kegiatan sekolah di luar lingkungan satuan pendidikan,

b. Mencegah anak melakukan tindakan kekerasan di lingkungan satuan pendidikan maupun dalam kegiatan sekolah di luar lingkungan satuan pendidikan

c. Mengatur mekanisme pencegahan, penanggulangan sanksiterhadaptindak kekerasandi lingkungan pendidikan yang melibatkan anak, baik sebagai korban maupun pelaku.

Pencegahan dan penanggulangan tindak kekerasan yang terjadi di sekolah yang melibatkan peserta didik tidaklah hanya diselesaikan dengan kebijakan penal saja, yaitu undangundang perlindungan anak dan peraturan mentri tetapi perlu juga menggunakan kebijakan di luar hukum (non penal). Menurut pendapat Paulus Hadisuprapto bahwa dalam penggunaan sarana penal dan non penal khusus untuk kebijakan penanggulangan kejahatan usia muda dan perilaku delinkuensi anak, kondisinya tidak berbeda, hanya saja penggunaan sarana non penal seharusnya diberi porsi yang lebih besar dari pada penggunaan sarana penal. Bila saja hal ini disepakati , maka berarti ada kebutuhan dalam konteks penanggulangan kejahatan usia muda dan perilaku delinkuensi anak. ${ }^{4}$

Perlunya sarana non penal diintensifkan dan diefektifkan karena masih diragukan atau dipermasalahkannya efektivitas sarana penal dalam mencapai politik kriminal. Bahkan untuk mencapai tujuan pemidanaan yang berupa prevensi umum dan prevensi khusus saja,

${ }^{4}$ Ibid 
efektivitas sarana penal masih diragukan atau setidak-tidaknya tidak diketahui seberapa jauh pengaruhnya. Menurut Donald R. Taft dan Ralph W. England bahwa efektifitas hukum pidana tidak dapat diukur secara akurat . Hukum hanya merupakan salah satu sarana kontrol sosial .kebiasaan, keyakinan ibadah, ,dukungan dan pencelaan kelompok, penekanan dan kelompok-kelompok interest dan pengaruh dari pendapat umum merupakan sarana-sarana yang efisien dalam mengatur tingkah laku manusia daripada sanksi hukum. ${ }^{5}$

Pendekatan sarana non penal yang dapat dilakukan untuk mencegah dan menanggulangi tindak kekerasan terhadap anak di lingkungan satuan pendidikan dapat dilakukan melalui peran sekolah, keluarga, masyarakat, dan pemerintah. Dalam hal tindak kekerasan yang terjadi di sekolah merupakan tanggung jawab utama ada pada sekolah sebagai pelaksana proses pembelajaran yang aman, nyaman dan

5 Donald R. Taft and Ralph W. England, Criminology, 1964 hal 31 menyenangkan bagi anak disamping melibatkan keluarga dalam hal 0rang tua juga memiliki andil dalam membentuk perilaku anak dalam

lingkungan keluarga.. Adapun pengertian keluarga sebagaimana didefenisikan dalam pasal 1 angka (3) undang-undang nomor 23 tahun 2002 tentang perlindungan anak adalah unit terkecil dalam masyarakat yang terdiri dari suami, istri dan anaknya, agar dapat hidup, tumbuh, berkembang dan berpartisipasi secara optimal sesuai dengan harkat dan martabat kemanusiaan, serta mendapat perlindngan dari kekerasan dan diskrminasi.

Keluarga merupakan lembaga pendidikan pertama dan utama dalam masyarakat, karena dalam keluargalah manusia dilahirkan, berkembang menjadi dewasa . Bentuk dan isi serta cara-cara pendidikan karakter anak di dalam keluarga akan selalu mempengaruhi tumbuh dan berkembangnya watak, budi pekerti dan kepribadian tiap-tiap manusia. Pendidikan yang diterima dalam 
keluarga inilah yang akan digunakan oleh anak sebagai dasaar untuk mengikuti pendidikan selanjutnya di sekolah. $^{6}$

Keluarga merupaka lingkungan pertama yang memberikan pengaruh terhadap berbagai aspek perkembangan anak, termasuk perkembangan sosialnya. Kondisi dan tata cara kehidupan keluarga merupakan lingkungan yang kondusif bagi sosialisasi anak; proses pendidikan yang bertujuan mengembangkan kepribadian anak lebih banyak ditentukan oleh keluarga, pola pergaulan, etika berinteraksi dengan orang lain banyak ditentukan oleh keluarga.

Persoalan mengenai konsep dan aplikasi nilai, maral dan sikap anak merupakan masalah yang sekarang ini sangat banyak meminta perhatian terutama bagi para pendidik dan orang tua. Terlebih tantangan zaman yang semakin kuat dengan

6 Ihsan Fuad, Dasar Dasar Kependidikan, Rineka Cipta Jakarta 200. Hal 12 adanya globalisasi dan slogan glabal village menjadikan anak (remaja) mudah terbujuk oleh gemerlapnya dunia hedonis, konsumeris yang makin menjauhkan anak dari nilai-nilai, moral, sikap dan perilaku keagamaan. Menurut Syamsu Yusuf bahwa perkembangan moral seorang anak banyak dipengaruhi oleh lingkungannya. Anak memperoleh nilai-nilai dari lingkungannya terutama dari orang tua. Dari pernyataan tersebut dapat dimengerti bahwa perkembangan moral anak sangat dipengaruhi oleh factor lingkungan sekitarnya, utamanya keluarganya yang setiap hari berinteraksi dengan anak. boleh jadi baik buruknya perkembangan moral anak tergantung pada baik dan buruknya moral keluarganya. ${ }^{7}$

Sistem pendidikan modern yang berkembang sekarang ini memandang anak sebagai sosok yang hidup dan aktif. Pendidikan modern sangat menekankan pemahaman akan

\begin{tabular}{lrr}
\multicolumn{1}{c}{${ }^{7}$ Syamsul } & Yusuf, & Psikologi \\
Perkembangan Anak Dan Remaja, Rosdakarya \\
Bandung hal. 23
\end{tabular}


kebutuhan maupun karakteristik anak/individu. Pemahaman akan kebutUhan dan karakteristik anak cukup membantu efisiensi pengarahan dan barangkali akan lebih membuat kita sabar ketika menghadapi mereka (anak-anak)ketika menjumpai kenakalan-kenakalan mereka yang kalau kita renungkan seringkali justru menggelikan ${ }^{8}$.

Pendidikan anti kekerasan

(non violence) mengindikasikan sebuah proses pembelajaran dengan penanaman sikap mental yang mengedepankan nilai-nilai positif anti kekerasan dalam menghadapi setiap permasalahan sosial, keagamaan dalam masyarakat. Pendidikan ini tentunya bertujuan untuk menghindari sikap egoistic (kekerasan). Pendidikan anti kekerasan perlu dibangun dari nilainilai yang berkembang dalam masyarakat, diantaranya nilai-nilai yang diambil dari agama, budaya dan juga hak asasi manusia. Pendidikan anti kekerasan untuk melindungi anak

\footnotetext{
${ }^{8}$ Idad Suhada, Perkembangan Peserta Didik, Remaja Rosdakarya, Bandung 2017. Hal 89
}

dari tindak kekerasan di sekolah seharusnya diperankan juga oleh keluarga sebagai salah satu upaya non penal dalam mencegah tindak kekerasan anak di ekolah.Untuk itu menurut penulis orang tua merupakan pendidik dalam keluarga, dan sebagai pendidik perlu memperhatikan beberapa hal yang harus dimiliki orang tua dalam mendidik anak yaitu :

1. Orang tua harus mengetahui pengetahuan tentang perkembangan karakter anak sesuai dengan usia-usia anak., sebab masing-masing usai anak tentu berbeda perkembangan karakternya, Orang tua harus pandai mendeteksi perkembangan perilaku anak sehingga orang tua dapat mengetahui model-model pendidikan karakter yang bagaimana yang dapat diterapkan pada anak sasuai dengan perkembangan usia anak.

2. Orang tua harus konsisten dalam mendidik anak. 
Orang tua harus memiliki sikap dan perlakuan yang sama

dalam melarang dan membolehkan tinggkah laku tertentu pada anak. pada kenyataannya masih saja dijumpai orang tua yang tidak kompak dalam mendidik anaknya berakibat kurang baik terhadap moral anak, biasanya mereka binggung membedakan mana yang baik dan mana yang buruk, mana yang boleh dan mana yang tidak boleh, patuh pada aturan bapak ataukah ibu, dan sebagainya. Orang tua harus menyamakan persepsi dalam memberikan pendidikan pada anak.

3. Sikap orang tua dalam keluarga sabagai panutan bagi anak.

Sikap orang tua dalam leluarga secara tidak langsung mempengaruhi perkembangan moral anak. melalui proses peniruan (imitasi) mereka merekam sikap bapak dan ibunya, dan sebaliknya sikap orang tua terhadap tetangga tetangga sekitarnya akan dengan mudah ditiru oleh anak, oleh karena itu sikap yang kekerasan dan otoriter orang tua akan membuahkan sikap kekerasan pada anak. sebaliknya sikap kasih sayang, lemah lembut, keterbukaan, musyawarah dan konsisten juga akan membuahkan sikap yang sama pada anak.

4. Penghayatan dan pengamalan agama yang dianut orang tua Orang tua harus menghayati ajaran-ajaran agama yang dianutnya. Sebab penghayatan ajaran agama mengandung nilai- nilai yang baik. Dan nilai nilai itulah yang akan diberikan kepada anak, baik berupa bimbingan-bimbingan maupun contoh implementasinya dalam kehidupan sehari-hari. Keteladanan orang tua dalam menjalankan moral keagamaan merupakan cara yang paling baik dalam menanamkan moral keagamaan anak. 
Banyak orang tua memahami kekerasan pada anak adalah hal yang wajar, mereka beranggapan bahwa kekerasan adalah bagian dari mendisiplinkan anak, mereka lupa bahwa orang tua adalah orang yang paling bertanggung jawab dalam mengupayakan kesejahteraan anak , perlindungan, peningkatan kelangsungan hidup dan mengoptimalkan tumbuh kembang anaknya. Menurut penulis anak yang berkembang dalam didikan keluarga yang selalu dengan kekerasan dapat mempengaruhi perkembangan moralnya yang mengarah pada perilaku kekerasan. Atau anak menjadi korban kekerasan orang tuanya dapat juga mempengaruhi perilaku kekerasan. Anak untuk melakukan tindakan kekerasan sesuai dengan apa yang anak saksikan atau anak alami sendiri di dalam keluarga, fenomena kekerasan yang dilakukan anak di sekolah juga dipengaruhi oleh adeganadegan kekerasan yang ditayangkan melalui televise. Ambil contoh acara televise yang mengandung televi kekerasan adalah filem anak langit, yang menceritakan geng-geng motor dengan action kekerasannya. Media elektronik seharusnya menayangkan acara acara yang televi makna edukasi .dan bukan untuk mempengaruhi perilaku anak. oleh sebab itu menurut penulis peranan keluarga harus nyata dalam pembentukan perkembangan kepribadian anak dengan membentuk perilaku anti kekerasan dengan menanamkan pendidikan nilai-nilai, moral dan sikap yang baik dari anak., peranan dimaksud menurut penulis adalah :

a. Keluarga dalam televise126 tua harus memberikan perhatian dan membangun kedekatan dengan anak. yang berbasis kasih saying dan kelembutan.. sikap orang tua yang penuh dengan kasih saying dan bahasa yang lembut dalam percakapan sehari-hari dengan anak , membangun keceriaan, suasana hangat dan nyaman selalu pada anak. keluarga harus membangun hubungan persaudaraan diantara anak- 
anaknya supaya mereka hidup penuh persahabatan, saling menghormati, penuh kasih televi. Sebaliknya suasana bermusuhan, perselisihan, iri hati, kebencian, kekerasan dapat berpengaruh pada perilaku anak.

b. Keluarga perlu menanamkan nilai-nilai agama pada anak. Agama memberikan suasana psikologis tertentu dalam mengurangi konflik, ftustasi dan ketegangan lainnya. Agama juga televi suasana damai dan tenang bagi anak. Ajaran agama ini merupakan sumber nilai , norma, kepercayaan dan pola-pola tingkah laku yang akan memberikan tuntutan arti. Dan tujuan hidup anak.

c. Keluarga dalam televise127 tua perlu memberikan ruang kegiatan bagi anak, kegiatan yang sesuai dengan minat anak dan nyaman bagi anak. kegiatan-kegiatan yang dapat melibatkan anak seperti berolah raga bersama, mengajak anak berkebun, kerja bakti membersihkan rumah, mengajak anak untuk selalu makan di meja makan bersama dengan orang tua dan lain-lain. kegiatan dimaksud berbasis kekeluargaan, keakrapan dan kasih televi, sehingga tercipta kesadaran anti kekerasan pada anak dalam bersikap.

d. Orang tua harus aktif dalam menanamkan empati pada anak. melalui empati ini tindak kekerasan bisa diantisipasi. Dalam keadaan marah saat rasa empati sudah tertanam dengan baik, maka ekspresi kekerasan tidak akan dilakukan, karena adanya kesadaran bahwa menyakiti itu akan membuat orang yang disakiti kasihan.

e. Orang tua harus memberikan penghargaan dan apresiasi bagi anak yang telah melakukan anti kekerasan dengan cara anak dapat meredam amarahnya,, menghentikan tindak kekerasan, menasihati teman 
untuk tidak melakukan kemarahannya. Anak dapat kekerasan,, memiliki rasa saang menjauhkan dirinya dari kekerasan. yang tinggi. Dengan apresiasi ini anak semakin yakin bahwa tindakan anti kekerasan baik untuk diri dan orang lain serta dihargai orang tua.

f. Orang tua harus mendampingi anak disaat menyaksikan siaran televise. Aksi-aksi kekerasan yang ditayangkan televise hendaklah tidak ditonton oleh anak.Orangtuaperlu mengarahkan anak untuk menonton acara televise yang memberikan edukasi bagi anak dan mengajar anak untuk menonton acara tayangan televise yang tidak ada televi kekerasannya..

Melalui penerapan langkah-langkah di atas maka keluarga telah melakukan peranan menjadikan anak yang berkarakter anti kekerasan, karena selalu mendahulukan empati, kesabaran dan kasih saying dalam mengekspresikan kekecewaan dan

\section{Penutup}

Tindak kekerasan terhadap anak yang terjadi di sekolah bukan saja menjadi tanggung jawab sekolah. Tetapi juga menjadi tanggung jawab keluarga. Peranan keluarga harus nyata dalam pembentukam perkembangan kepribadian anak terhadap perilaku anti kekerasan, Orang tua harus menjadi pendidik dalam keluarga sehingga hal-hal yang perlu diketahui oleh orang tua adalah memahami perkembangan perilaku anak sesuai dengan usia anak, orang tua harus konsiten dalam mendidik anak, orang tua harus bersikap yang seharusnya dalam keluarga, serta penghayatan dan pengamalan ajaranagama. Dengan membekali dirinya, maka orang tua dapat menanamkan nilai-nilai, moral dan sikap yang baik bagi anak. Peran keluarga dimaksud adalah memberIkan perhatian dan membangun kedekatan dengan anak, yang berbasis kasih saying dan kelembutan, menanamkan nilai-nilai 
agama, menanamkan rasa empati pada anak, memberI ruang kegiatan pada anak sesuai minat, memberikan penghargaan dan apresiasi pada anak yang telah melakukan anti kekerasan, serta mendampingi anak menyaksikan acara tayangan televise.

\section{Daftar Pustaka}

Arif , Barda Nawawi (1996) : Bunga Rampai Kebijakan Hukum Pidana. Citra Aditya Bakti. Bandung.

Suharda Idad, (2017), Perkembangan Peserta Didik . Remaja Rosdakarya. Bandung,

Ihsan Fuad. (2003) Dasar-Dasar Kependidikan . Rineka Cipta. Jakarta 2003

Paulus Hadisuprapto, (1997) Juvenile Delinquency( Pemahaman dan Penanggulangannya), Citra Aditya Bakti, Bandung

Syamsu Yusuf, (2007) Psikologi Perkembangan Anak Dan Remaja, Rosdakarya Bandung 